\title{
HISTORIESE OORSIG VAN DIE ONTSTAAN EN ONTWIKKELING VAN DIE MILITÊRE LUGVAART EN DIE SELFSTANDIGE LUGMAGTE
}

\section{Die ontstaan vàn die militêre lugvaart}

Vir eeue het die wêreld net twee soorte oorloë geken - dié op land en dié ter see. Teen die tweede helfte van die 18de eeu is egter ook die lugruim vir oorlogvoering aangewend. In dié verband word aan die gebruik van ballonne ter ondersteuning van die landoorlog gedink. Die Franse Leër het reeds so vroeg as 1789 'n ballonkorps gehad en in 1849 is die eerste bomaanval in die geskiedenis deur Oostenryk, met behulp van 'n onbemande ballon, teen Venesië geloods. Die belangrikste vroeëtydse aanwending van ballonne in oorlogsvoering was egter gedurende die jare 1862-1863 tydens die Amerikaanse Burgeroorlog en gedurende die Frans-Pruisiese Oorlog (1870-1871). Taktiese lugoperasies is dus die oudste vorm van militêre lugvaart en aangesien dit ter ondersteuning van sekere leërfunksies aangewend is, is die krygsmiddel ter uitvoering hiervan dan ook by die leër ingedeel.

In 1903 het die broers Wright die verbeelding van die wêreld aangegryp toe Orville op die 17de Desember 120 voet in 12 sekondes gevlieg het! Met die koms van die vliegtuig het die beperkte moontlikhede van die ballon dan nou ook opgeval. Hoewel die wêreld skepties teenoor die vliegmasjien gestaan het, het die Russe, Franse, Britte en Duitsers ernstige aandag aan militêre lugvaart begin skenk.

2 Die ontwikkeling van die militêre lugvaart en die ontstaan van selfstandige lugmagte met besondere verwysing na Engeland, Duitsland, die U.S.S.R. en die V.S.A.

\section{a Voor Wêreldoorlog $I$}

In 1908 het die Imperial All-Russia Aero Club ontstaan. Hierdie organisasie was verplig om sy vliegtuie aan die Russiese Ministerie van Verdediging beskikbaar te stel. In 1910 het die Russiese Tegniese Genootskap 'n lugvaartkundige afdeling aan die organisasie toegevoeg. Hoewel daar vooruitgang ten opsigte van militêre lugvaart in Rusland te bespeur was, was dit - as gevolg van ondoeltreffende organisasie - maar stadig. Voor 1912 is die Tsaristiese Lugmag deur die lugvaartafdeling van die Genie, onder beheer van die Departement van Verdediging, beheer. In 1912 en 1913 is dié opset egter gewysig. Die Russiese Tsaristiese Vloot, daarenteen, het klaarblyklik sedert 1910 sy eie vliegtuie beheer. In die militêre distrikte is lugvaarteenhede (eskaders) onder 'n gebiedsbevelvoerder aan 'n leërkorps en hoër formasie toegevoeg en, op dieselfde wyse, forteskaders aan besondere militêre installasies - 'n stelsel wat in wese nie veel van die huidige Russiese opset verskil nie.

Die Britse maneuvers wat in 1912 gehou is, was vermoedelik die begin van die geskiedenis van die Britse Lugmag.

Vliegtuie is egter, behalwe vir verkenningsdoeleindes, nie van veel waarde beskou nie.

Sover dit die ontwikkeling in Duitsland betref, vind ons dat in 1911, behalwe kavallerie en 'n lugskip, ook 'n paar vliegtuie by maneuvers 
vir waarnemingswerk gebruik is. In 1912 het die Duitse Vlootlugdiens tot stand gekom en in 1913 is dit verdeel in 'n Marine Luftschiffabteilung en 'n Marine Fliegeabteilung. Laasgenoemde is egter tot 1917 verwaarloos.

Op 1 Augustus 1907 het Brig.-genl. James Allen, hoofsenioroffisier van die Amerikaanse leër, 'n memo onderteken waarin verklaar is:

An Aeronautical Division of this office is hereby established, to take effect this date... This division will have charge of all matters pertaining to military ballooning, air machines, and all kindred subjects'.

Dit kan as die begin van die U.S.A.F. beskou word. Teen 1911 het die Army Air Arm oor een vliegtuig en een vlieënier beskik en ten spyte van verdere ontwikkeling en vooruitgang op die gebied van militêre lugvaart het die V.S.A. teen 1912 by Engeland, Duitsland en Frankryk agter gestaan. Laasgenoemde kan toegeskryf word aan die feit dat die V.S.A. geen vyandelike buurstate gehad het nie. In 1913 is 'n onsuksesvolle poging aangewend om die Lugmag van die Seinkorps te laat weg. breek en as 'n afsonderlike organisasie te laat optree en op 18 Julie 1914 is The bill created in the Signal Corps an Aviation Section aangeneem.

Uit voorafgaande blyk dus duidelik dat, alhoewel daar voor 1914 reeds die moontlikhede van die vliegtuig as 'n praktiese en effektiewe wapen ingesien is, die leiers van die groot moondhede weinig gedoen het om dit as sodanig te ontwikkel.

\section{b Wêreldoorlog I}

Toe die Eerste Wêreldoorlog in 1914 uitbreek, het al die oorlogvoerende partye die een of ander lugvaartkundige organisasie, oor 'n handvol vlieëniers beskik wat hoofsaaklik vir verkenning opgelei is en 'n beskeie aantal diensbare vliegtuie gehad. In hierdie oorlog sou die vliegtuig hoofsaaklik ten behoewe van die land- en seemagte aangewend word en 'n ondergeskikte ondersteuningswapen van die leër en vloot wees. Aangesien die pogingskaal op land die grootste sou wees, sou die leërbehoeftes oorwegend wees en sou die leër derhalwe ook die grootste lugmagte opbou. Tot 1915 is die vliegtuig egter bloot as ' $n$ plaasvervanger vir ligte kavallerie beskou — 'n middel om die vyand se opstelling mee waar te neem en om sy planne te probeer vasstel. Leërbevelvoerders het die vliegtuig slegs as die oë van die grondmagte beskou. Toe die vegtendes egter besef dat die vliegtuie dikwels baie waardevolle informasie insamel en dus 'n nuttige oorlogswapen word, het dit duidelik geword dat iets gedoen sal moet word om vliegtuie te verhinder om met hulle verkenningswerk voort te gaan. Dit was die konsepsie wat tot die geboorte van lugverdedigingsoperasies gelei het. Ook het dit duidelik geword dat die vliegtuig baie nuttig vir grondsteunaanvalle, die lei van artillerievuur, die vervoer van personeel en om bomme af te gooi, kan wees - 'n uitbreiding van sy taktiese rol dus. Die beperkinge van die vliegtuig as bommer het egter daartoe gelei dat die lugskip vir dié doel ontwikkel is. In hierdie verband word veral gedink aan die beroemde Duitse Zeppelin. Die lugskip was vanweë sy kwesbaarheid egter nie baie doeltreffend nie. 
Gedurende die eerste vier jaar van die oorlog was die ontwikkeling van militêre lugvaart besonder snel. Die druk van die aktiewe oorlogsvoering en die daaglikse kompetisie om lugoormag oor die Europese slagvelde te verkry, het tot die snelle ontwikkeling van die militêre vliegtuig gelei. Gespesialiseerde vliegtuie vir spesiale take is ontwerp en so het vegters, bommers en verkenningsvliegtuie die lig gesien. Met hierdie ontwikkeling van die vliegtuig en die lugoorlogvoering moes lugmagorganisasies egter ook tred hou.

In Engeland is, met die uitbreek van die oorlog, vliegtuie aan die Britse Vloot (Royal Naval Air Service, R.N.A.S.) toegevoeg, terwyl die Britse Leër oor die Royal Flying Corps (R.F.C.) beskik het. In 1916 is die Air Committee onder lord Derby in die lewe geroep om die toekomstige plek van genoemde organisasies binne die raamwerk van die Britse strydkragte te bepaal. Hierdie poging het, as gevolg van die sterk invloed van Leër- en Vlootkringe en gebrek aan tegniese kennis, misluk. Daarna is 'n kommissie onder lord Curzon met dieselfde taak belas. Vordering is gemaak ten opsigte van die bevoorrading en verspreiding van vliegtuie, maar aldus Sims in The Royal Air Force: The First Fifty Years.

Without ministerial authority little could be done to control the operational effectiveness of two combatant air Services or to insist on a common policy aimed at winning the war in the air.

In 1917 is die Cowdray-komitee met die taak belas. Die produksie van vliegtuie is onder ministeriële beheer geplaas wat die bevoorrading aan die R.N.A.S. en die R.F.C. gereël het. Die Cowdray-komitee het kort daarna 'n verhoogde status, diê van 'n Lugvaartraad (Air Board) verkry, wat die eerste stap in die rigting van die toekomstige Britse Departement van Lugvaart (Air Ministry) en die totstandkoming van 'n strategiese lugmag (Strategical Air Arm) was. Vordering is voorlopig, as gevolg van mededinging en onwilligheid van die kant van die Britse Vloot en die Britse Leër, nie gemaak nie. Daarna is, in 1917, 'n komitee onder voorsitterskap van Genl. J. C. Smuts in die lewe geroep. Aanbeveel is dat:

i. Die Lugvaartraad 'n departement (ministerie) word.

ii. 'n Minister met volledige seggenskap aan die hoof van hierdie departement kom.

Vervolgens is die Air Force Bill aan die Britse Parlement voorgelê. Die ontwerp het op 29 November 1917 die koninklike goedkeuring verkry, wat tot die stigting van 'n lugministerie en op 1 April 1918 tot die stigting van die R.A.F. gelei het.

In verband met Genl. Smuts se aandeel en sienwyse in voorafgaande verband verklaar Sims o.a.: His belief in a separate Air Force was expressed with fervour. By Nancy (Frankryk) was 'n aantal bomwerpeskaders (R.A.F.) saamgetrek, wat in Oktober 1918 die eerste nagtelike aanval op doelwitte in die Saargebied uitgevoer het. Sims verklaar, met verwysing na dié gebeurtenis: This really was the start of operations by an independent air arm. 
Ten tye van die begin van die Eerste Wêreldoorlog het die Duitsers lugskepe en vliegtuie in groepe langs die front (België) geplaas. Laasgenoemde was bedoel vir verkenning en lugfotografie. Hierdie Feldflieger-Abteilungen was deel van die Duitse Weermag. Aan elke Leërhoofkwartier was een afdeling toegevoeg. Ook is een aan elke korps toegevoeg

In 1916 besluit Genl. Ludendorff dat die vliegtuie van die Leër moet wegbreek. Dié gedagte lei tot die oprigting van die Deutsche Luftstreitkräfte, die voorloper van die Luftwaffe, as 'n afsonderlike Army Command met 'n generaal onder die stafhoof.

Die geskiedenis van die Duitse Lugmag in die Eerste Wêreldoorlog kan in die volgende woorde saamgevat word: Im Krieg geboren, im Krieg gestorben.

Gedurende die Eerste Wêreldoorlog het die Russe, te midde van ' $\mathrm{n}$ rewolusie, gepoog om die militêre lugvaart uit te brei en te moderniseer. In 1917 is die General Command of the Aerial Fleet, Aviation Supply Depots, and Inspectorate opgerig. Beheer is uitgeoefen deur die All Russian Aviation Board. Vanaf 1918 is vlootvliegtuie deur die Vlootlugmag beheer. Origens het die ontwikkeling en optrede van die Russiese Imperiale Lugmag maar swak met dié van die ander strydende moondhede vergelyk.

Die V.S.A. het eers na drie jaar tot die oorlog toegetree met as belangrikste vliegtuig, die verkenningsvliegtuig. Op 24 Julie 1917 neem die Kongres die Aviation Act aan. Fondse was voldoende, dog vliegtuie en kennis i.v.m. oorlogvoering egter onvoldoende. Die vertraging in die vliegtuigbou lei tot die Overman Act van 20 Mei 1918, waarby die lugvaart aan die Seinkorps onttrek is onder die nuwe benaming: Air Service, U.S. Army. Beheer oor produksie sou by die Army Bureau of Aircraft Production berus en albei sou afsonderlik aan die Minister van Verdediging verslag doen.

Teen die einde van die oorlog het die Duitsers se begeerte om Londen onder die bomme te laat deurloop tot 'n verdere ontwikkeling van die militêre lugvaart gelei. Die waarde van die swaar bomwerper as ' $n$ strategiese wapen is ook nou besef.

Die komitee, wat onder voorsitterskap van Genl. J. C. Smuts tot die stigting van 'n lugministerie en die R.A.F. in Engeland gelei het waarna vroeër verwys is, het o.a. die volgende opmerking in hulle verslag gemaak:

As far as can at present be foreseen there is absolutely no limit to the scale of its (air power's) future independent war use. And the day may not be far off when aerial operations with their devastation of enemy lands and destruction of industrial and populous centres on a vast scale may become the principal operation of war, to which the older forms of military and naval operations may become secondary and subordinate.

Trenchard was veral die een wat die vliegtuig as a primarily offensive weapon gesien het en strategiese bomming en 'n unified air command bepleit het. Sy filosofie het uiteindelik ingang gevind en in Oktober 1918 is hy as opperbevelhebber van die Inter-Allied Independent Bombing Force aangestel. Die oorlog was egter reeds gewen. Die ontwikkeling was nogtans rigtinggewend vir die toekoms. 
In die tydvak tussen die twee wêreldoorloë het militêre lugvaart fenomenaal ontwikkel. Die periode is veral gekenmerk deur dit uitbouing van die leer van strategiese oorlogsvoering deur manne soos Trenchard, William Mitchell en veral die Italianer, Giuilo Douhet. Sy eerste en basiese leerstelling was: Resist on the grond in order to mass in the air! Volgens hom moes 'n land se militêre hulpbronne hoofsaaklik in lug$\mathrm{krag}$, of te wel 'n onafhanklike lugmag, gekonsentreer word, i.p.v. om dit in die leër en vloot te versprei. Die lugmag moet gebruik word om die vyandelike lugmag op die grond te neutraliseer en dan teen die moreel van die bevolking aangewend word. So het die konsep van lugkrag in die sin van strategiese bomming, ten einde toe lugoorwig ten behoewe van landoperasies te kom, vorm aangeneem - 'n konsep wat in wese, werking en doel onafhanklik van die leër en vloot is en waarby interdiksie tot 'n sekere mate ook inbegrepe is. Douhet se teorie het met groot aanhang sowel as teenstand te doen gekry, maar dit het in elk geval die militêre denke en die openbare mening tussen die twee oorloë beïnvloed. Dit het o.m. daartoe gelei dat verskeie lande in Wes-Europa hul grondstrydmagte verwaarloos het. Dit het die wil tot verset teen 'n oorheersende lugmag verswak. As gevolg van sy leer was die mees belangrike ontwikkeling gedurende 1918-1939 dan ook die ontwikkeling van die langafstandbommer.

In Desember 1918 word Winston Churchill onder meer Minister van Lugvaart. In 1919 is die vredestydse organisasie van die R.A.F. in die vorm van 'n witboek aan die Britse Parlement voorgelê. Sims verklaar:

By 1923 the Government had not only confirmed the status of the R.A.F. and Air Ministry but had agreed to its modest expansion ... This was a positive step forward and one which acknowledged the fact that Air Defence was a prime national consideration.

In 1924 is die Fleet Air Arm onder beheer van die Britse Admiraliteit in die lewe geroep. Tussen 1920 en 1930 is troepe- en vliegtuigdraers aangeskaf. In 1936 is die Air Defence of Great Britain-organisasie vervang deur gespesialiseerde kommandemente. Verder is ook voorbereiding ten opsigte van die ryksverdediging getref. Omstreeks hierdie tydstip is 'n aanval deur die R.A.F. as die doeltreffendste wyse van verdediging beskou. Daar is op grond hiervan dan ook op bomwerper- en vegter-eskaders toegespits.

In 1922 is die verdrag van Rapallo tussen Rusland en Duitsland gesluit. Dié verdrag het 'n geheime klousule bevat, nl. dat Rusland 'n ou vliegveld ter beskikking van die Reichswehr sal stel. Vliegtuie en personeel volg in die geheim. In 1933 belas Rykskanselier Hitler vir Goering, Minister van Lugvaart, in die geheim met die skepping van die Luftwaffe. Die basis in Rusland is gesluit en toekomstige vlieëniers is nou in die geheim na Italië waar hulle elke aspek van moderne oorlogvoering oefen en die Blitzkrieg-gedagte, deur op ondersteuning van 'n invalsmag te konsentreer, ontwikkel. In Maart 1935 tree die Luftwaffe openlik as 'n onafhanklike deel van die Duitse Weermag met Goering as General der Flieger, sy tegnici e.a. te voorskyn. Goering was deur die Minister van Verdediging aan Hitler verantwoordelik. Die kern van die Luftwaffe is deur ligte- en middelslagbomwerpers, vir aanwending in die taktiese rol, gevorm. 
In Rusland het die Rewolusionêre Militêre Komitee, onder Trotsky, alle weermagsaktiwiteite gekoördineer. In November 1918 kom die Council of Workers and Peasants Defence of the U.S.S.R. onder die Militêre Komitee tot stand. Teen 1923 het die Kommissariaat van Militêre en Vlootaangeleenthede sterker regstreekse beheer oor die Generale Staf, deur die Opperbevelhebber van die Gewapende Magte, uitgeoefen. Een van die afdelings van genoemde Kommissariaat was die Hoofdirektoraat van die Lugmag van die Rooileër. Laasgenoemde het tegniese, administratiewe en taktiese beheer oor die landlugmagte uitgeoefen. Die taktiese beheer is volgens Kilmarx in sy boek $A$ History of Soviet Air Power, beperk

by the fact that the air units assigned to each military district were under the immediate operational direction of the Red Army Military district commander, (through the local Revolutionary Military Councils) or subordinate army formations . . Naval, subordinate to fleet commannders.

Tussen 1923 en 1928 is die interne organisasie van die Hoofdirektoraat gereël en onder meer 'n Generale Staf (Lugmag) daargestel. Vordering tot 1932 was egter nie na wense nie.

As in most other air forces at this time, doctrinal disputes over the role of air power interferred with the changes dictated by technological progress, and there was little chance to profit from combat experience,

aldus Kilmarx.

Tussen 1933-1941 het buitelandse bedreigings en binnelandse spannings tot verdere opbou en gereedheid i.v.m. moontlike operasionele optrede gelei. In 1941 was Rusland egter nog nie gereed nie. As gevolg van die absoluut beheer wat die Regering oor die gewapende magte uitgeoefen het, het die filosofie van Douhet nie veel ingang in Rusland gevind nie.

Die Amerikaanse leiers het daarenteen in die filosofie soos deur Trenchard verkondig is, geglo: . . the airplane is a primarily offensive weapon. Tussen 1919 en 1920 is planne beraam i.v.m. die losmaak van die Air Service, dog in 1920 volg die U.S. Army Reorganization Act wat die Air Service a combatant arm of the Army gemaak het.

The War Department insisted that the tactical squadrons operate under control of the Army commanders as integral elements of divisions and corps, aldus MacCloskey.

1920-1925 was jare van stryd om vir die Lugmag volledige erkenning te verkry. In 1926 volg die Air Corps Act en die Air Service verander in die Air Corps, dog nog steeds aan die Leër ondergeskik. Teen 1933 het baie lugmagoffisiere gevoel dat dit nutteloos sal wees om die stryd om 'n onafhanklike Lugmag voort te sit. They elected to adopt as a temporary solution the creation of a GHQ Air Force (MacCloskey), wat dan ook in 1935 in werking getree het. Die Bevelvoerende Generaal Hoofkwartier Lugmag - waaronder die Air Corps geval het - sou in vredestyd onder die Hoof van die Generale Staf en in oorlogstyd onder die Bevelhebber Veldmagte staan. Wrywing ontstaan egter op administratiewe vlak a.g.v. verdeelde gesag tussen die Air Corps en die Korps se gebiedsbevelvoerders. Op 1 Maart 1939 is die G.H.Q. Air Force onder die jurisdiksie van die Chief of Air Corps geplaas en in 1940 weer losgemaak om afsonderlik onder die Commander, Army Field 
Hierdie reëlings het egter onbevredigend geblyk. In Maart 1941 is die Leër as lugtak onder een bevelvoerder geplaas en in Junie the Army Air Forces (A.A.F.) was created to co-ordinate and direct the activities of the Air Force Combat Command and the Air Corps. Een van die belangrikste redes vir die daarstelling van die A.A.F. was om wrywing tussen vegtende- en dienseenhede uit te skakel. Dit het egter nie geluk nie. Botsings tussen die Hoof van die A.A.F. en Groothoofkwartier van die Leër volg en op 6 Julie 1941 kry die Leër Groothoofkwartier oor beplanning en operasies beheer. 'n Kommissie word met die oog op reorganisasie aangestel en in 1942 kom drie outonome en gelyke organisasies onder die Stafhoof V.S.A. Leër tot stand, t.w. die $A . A . F$., Army Ground Forces en Services of Supply (1943 - Army Service Forces).

\section{d World War II}

The importance of World War II was greater than as a test of Douhet's theories. Whether or not the general emphasis on strategic bombing was proved right, it was clearly shown that ground fronts need not remain static; that conventional bombs had less destructive power than Douhet supposed; that, largely because air forces had to make repeated sorties to achieve their results, aerial defences were of much greater effectiveness than he had thought likely; and that neither civilian morale nor the economy of any great nation was as vulnerable as Douhet thought. Thus, the frequent assertion that Douhet's ideas were proved right by World War II cannot be accepted. However, Douhet deserves credit for having foreseen, more clearly than his critics, the enormous importance of strategic bombing in the future and also the importance of fighting the air battle by hitting suitable targets on the ground, rather than in the air.

To assess the real contribution of strategic bombing in World War II, is difficult. Against Germany it produced decisive results only in the very last stages of the war when, first the German oil and chemical industries and, later, the transportation system were effectively paralyzed. However, by that time the German armies were already beginning to be defeated in the field, thus the disasters at home had contributed rather little to that defeat. However, the Allied srategic bombing campaign launched against German oil supplies led to a shortage of fuel supplies which in turn resulted in inadequate pilot training, both quantitatively and qualitatively. This inadequacy led to a further decrease in German efficiency in the air with a corresponding increase in Allied air superiority. It was thus a contributing factor to the outcome of the war. The part of the strategic bombing campaign that contributed most effectively to the success of the Allied Armies, was the destruction of the German Air Force, mainly by direct attacks on German airfields. The greatest successes for air power in World War II, however, are to be found more in the fields of tactical military aviation, both on land and at sea, than in strategic bombing.

World War II was the testing ground for air warfare in all its facets and many lessons were derived from it, new definitions of air power formulated and views to the latter expressed:

i Air power includes a nation's ability to deliver cargo, people, destructive missiles and warmaking potential through the air to a desired destination to accomplish a desired purpose. Air power 
is not composed alone of the warmaking components of aviation. It is the total aviation activity - civilian and military, commercial and private, potential as well as existing. (Genl. Arnold).

ii Tactical and strategic air power are part of the same ball of wax. (Genl. Hoyt S. Vandenberg).

iii The air battle must be won if a war is to be won. (Genl. Omar N. Bradley).

iv The Air Force's primary mission to knock out enemy air power to win the air war. (Genl. Arnold).

v Destroy the Enemy Air Force wherever you find them, in the air, on the ground and in the factories. (Genl. Arnold).

vi Land forces cannot fight decisively unless the air is controlled by its sister services. (Lt.-Genl. Manton S. Eddy).

vii Nothing could be more fatal to successful results than to dissipate the air resources into small packets placed under command of army formation commanders, with each packet working on its own plan. (Genl. Montgomery).

viii The greatest asset of air power is its flexibility and this flexibility could be realized only when air power was centrally controlled by an air officer who would maintain a close association with the ground commander. (Genl. Montgomery).

ix Battle experience proved that control of the air, the prerequisite to the conduct of ground operations in any given area, was gained most economically by the employment of air forces operating under a single command. This assured a maximum of flexibility, providing a command structure under which all forms of available air power could be concentrated on tactical support missions or on strategic missions, as the situation demanded - in other words, it permitted the maximum concentration of combat air power at the decisive point at the decisive time. (Genl. Eisenhower).

$\mathrm{x}$ U.S. Army and A.A.F. officers were so generally satisfied with the air ground system that had matured in Europe that it was incorporated into War Department Field Manual 31-35, AirGround Operations, in August, 1946. Written as an assimilation of the best lessons of World War II, this manual stated: The forces within a theatre are composed of air, ground, and naval components. Unified command is vested in the theatre commander, who is directly responsible for the administration and combat operations within the theatre. It is his responsibility that operational plans provide for co-ordination of the force at his disposal and that such plans are energetically and effectively executed.

$\mathrm{xi}$ If history is to be considered as nothing more than the exact record of accumulated experience, one must conclude that the Allied strategic air operations of World War II did not attain the goal of producing surrender with only incidental help from other sources. On the basis of facts, one must conclude that World War II represented an Allied victory attained with co-ordinated air, ground, and naval forces. (MacCloskey). 
The value derived from World war II for the R.A.F. was that

Its character . . . had been shaped and developed . . Its sponsors had, from the very early days and despite the intrigues and discouragement of sailors, soldiers and politicians pursued the idea that the air weapon was the decisive power of the future. It had trained and worked to that end. (Sims).

The German offensive on the eastern front was marked by the use of the Luftwaffe as a tactical support weapon. Hitler did not make provision for fighters and long-range bombers to destroy Russian military targets and industries.

Hitler and his supreme command did not understand the true nature of air power - particularly the importance of air supremacy - and did not appreciate the limitations, as well as the strengths, of the air forces. (Kilmarx).

Further he bargained on Defeating Russia before November 1941 by means of a series of Blitzkriegs. He did not prepare for a drawn-out war and, in the light hereof, refused to alter his strategy. After the question of air superiority had resolved itself, largely due to the success of the Allied strategic bombing attacks on German oil and aircraft, the Soviet use of air power, whatever their shortcomings in the way they employed it as a tactical weapon in the close support role, was masterly. As far as the U.S.A. is concerned, World War II moulded the A.A.F. into the U.S.A.F. which was established by the National Security Act of 1947.

e After World War II

Air power emerged clearly as the dominant mode of warfare after World War II. The bomber with its nuclear carrying capability became the symbol of military power. The strategic thinking of the major powers was increasingly centred around the concept of destroying an enemy's capacity to wage war by attacking his centres of production with nuclear weapons. The remarkable technological advances in jet propulsion, nuclear weapons and guided missiles during the post-war period lent still greater emphasis to this concept of warfare. But in spite of the intense competition between the U.S.A. and the U.S.S.R., neither nuclear weapons nor guided missiles were used in the Korean War and the latter, being a limited war, therefore did not prove to be a preview of the air warfare of the future.

There can, however, be no doubt that the advent of nuclear weapons has established the dominance of strategic bombardment in any unrestricted war in the future. If Douhet exaggerated the effects of H.E. bombs, then nuclear weapons have far more than just made up the difference. In fact, it could be said that because of other technological affecting both the offence and the defence in strategic bombing, Douhet's philosophy, and indeed the whole idea of strategic bombing, would now be absolutely dead if it were not for nuclear weapons.

For the future it may be said with assurance that in an unrestricted nuclear war the role of air power, using aircraft and missiles, will be dominant and decisive. It will be destructive to the point of annihilation to one side at least. The only political objective that can be served thereby it at the elimination of the enemy. This pre-supposes that one can hit first and also hard enough to reduce drastically, if not to eliminate, his chances of retaliation. 
As far as limited war is concerned, everything depends on the nature and degree of limitation. If the use of nuclear weapons can be avoided, then the manipulators of air power have to reconcile themselves to playing a supporting role to ground forces. In that case the doctrinal preference for air superiority and interdiction, which had Douhet's sanction, and which permits the air force an independent mission, still remain valid. However, the use of nuclear weapons is bound to increase the relative importance of air power, and air forces may thus be expected to have a bias for their use. The chief danger in their use, however, is that it will be more difficult to keep war limited. The best guiding line for the future could perhaps be derived from the following statement by McCloskey:

The guiding principle in pursuing the national objectives is to limit military force to those systems and intensities appropriate for the special issues at stake. Military forces must be used in a manner that denies the agressor his objectives - through persuasion or by destroying war termination... In sum, we must have controllable forces which can provide a flexible response to any level of aggression, supported by strategic superiority at the highest level of conflict, if we are to ensure a credible deterrent posture for the future.

The watchwords for peace remain: Strength and determination. The strength to deter any potential aggressor; the determination that the carnage of two world wars must never be repeated again. (Killen, The Luftwaffe. A History, London, 1967).

Slot

Die huidige opset van die Lugmagte onder bespreking is aan u bekend. Omstandighede het veranderings gedwing, dog basies verskil hul opset nie van die grondbeginsels waarop hulle ontstaan en ontwikkel het nie. Die ontstaan en ontwikkeling van die S.A.L.M. is ook aan u bekend. Tog wil ons net daarop wys dat die S.A.L.M. die tweede selfstandige Lugmag in die Britse Ryk was. Teen die agtergrond van hierdie beknopte historiese oorsig van die ontstaan en ontwikkeling van militêre lugvaart en selfstandige lugmagte gesien, is dit ook duidelik dat die S.A.L.M., in sy huidige opset, die resultaat is van 'n ontwikkeling gebasseer op die lesse wat deur groot moonhede uit die verlede geput is.

Die S.A.L.M. het, na ons mening, vanaf sy totstandkoming egter een groot voordeel bo ander lugmagte gehad, nl. dat dit saam met die Leër en later die Vloot onder een departement geressorteer het. Dit het die wrywing tussen die weermagsdele, wat so kenmerkend was van die Lugmag se stryd om selfbeskikking in ander weermagte, sowel as die probleem van samewerking uitgeskakel. Met die instelling van 'n geïntegreerde bevelstruktuur in 1965 is samewerking tussen die drie weermagsdele verder bestendig deur die daarstelling van die nodige masjinerie vir gesamentlike optrede.

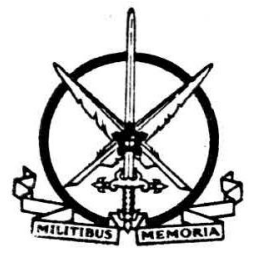




\section{SUMMARY}

In his introduction the writer draws attention to the fact that where warfare was initially limited to land and sea, the air space was also being used for this purpose in the closing quarter of the 18th Century.

The oldest form of military aviation is tactical air operations and since this was used in support of certain army functions the combat method of executing this function was assigned to the army.

This was not only the case in respect of the 19th Century application of air balloons, but also referred to the first aircraft. In this regard a review is first of all given for the early development of the military air force in our country and the development of independent air forces (Britain, Germany, U.S.S.R. and U.S.A.).

Initially the military aircraft was regarded as the eyes of the ground forces. The next phase comprised efforts in an attempt to prevent air reconnaissance. This was the beginning of air defence.

The aircraft was also regarded as being useful for ground support attacks, as a pathfinder in respect of military fire, the transport of personnel and bombing. In the latter respect the airship enjoyed temporary preference. In England we initially find the Royal Naval Air Service (R.N.A.S., Navy) and the Royal Flying Corps (R.F.C., Army). On 1 April, 1918, the Royal Air Force (R.A.F.) began its history as an independent organisation. In Germany the Feldflieger Abteilungen originally formed part of the Defence Force, but in 1916 it was decided to establish the Deutsche Lufstreitkräfte the precusor of the Luftwaffe, as an independent military organization. In Russia in 1917 the General Command of the Aerial Fleet Aviation Supply Depots and Inspectorate was established whilst the U.S.A.'s aircraft were withdrawn from the Signal Corps in 1918 and became known as Air Service U.S. Army.

In England, Lord Trenchard had for a considerable time already regarded the military aircraft particularly as a weapon of attack, a viewpoint which found strong support after World War I and which influenced military aviation.

Also the Italian, Giulio Douhet, influenced military aviational thought by making a plea for an independent air force which had to be used to procure dominance in the air in support of ground operations and to influence the morale of the population.

In England troop and aircraft carriers were required between 1920 and 1930. In Germany the Luftwaffe made its appearance as an independent arm of the German Wehrmach and on 1 February, 1920, the South African Air Force (S.A.A.F.) appeared on the scene.

The World War II, inter alia, proved on the one hand that Douhet's theories could not be regarded as valid in all respects. On the other hand, his predictions on the importance of strategic bombing and the value of air attacks on ground positions, were realized.

Next, the writer refers to the effect of strategic bombing on Germany and the fact that the World War II constituted an important trial period for air warfare.

After World War II the technological advances, particularly in the field of nuclear weapons created new perspectives and also previously unknown problems. The writer holds the opinion that, in the case of unlimited nuclear war the role of the air weapon would be dominant and conclusive. 
In respect of limited warfare the writer is of the opinion that this would depend on the nature and the extent of the limitations imposed. In conclusion he refers to a statement made by MacCloskey that it is the great task to have "controlable forces, which can provide a flexible force to any level of aggression supported by strategic superiority at the highest level of conflict if we are to ensure a credible deterrent posture to our future."

According to him the South African Air Force has the great advantage of falling under one department from the beginning. Accordingly the problems of self-determination and co-operation which initially impeded joint action in other countries, did not exercise a stagnating influence here.

\section{OPSOMMING}

In sy inleiding vestig die skrywer die aandag op die feit dat, waar die oorlogvoering aanvanklik tot die land en die see beperk was, tydens die laaste kwart van die 18 eeu ook die lugruim vir die doel aangewend is.

Die oudste vorm van militêre lugvaart is taktiese lugoperasies en aangesien dit ter ondersteuning van sekere leërfunksies aangewend is, is die krygsmiddel ter uitvoering hiervan by die leër ingedeel.

Dit was nie alleen die geval ten opsigte van die 19e eeuse militêre aanwending van lugballonne nie, maar ook met betrekking tot die eerste vliegtuie.

In hierdie verband bespreek die skrywer allereers dié vroeë ontwikkeling van die militêre lugmag in ons eeu en die ontstaan van selfstandige lugmagte (Engeland, Duitsland, die U.S.S.R., die V.S.A.).

Aanvanklik is die militêre vliegtuig as die ö̈ van die grondmagte beskou. Die volgende fase was dat pogings aangewend is om lugverkenningswerk te probeer verhinder. Dit was die begin van die lugverdediging.

Die vliegtuig is ook as nuttig vir grondsteunaanvalle, as padvinder vir artillerievuur, die vervoer van personeel en bomwerping beskou. In laasgenoemde opsig het die lugskip tydelik voorkeur geniet.

In Engeland het aanvanklik die Royal Naval Air Service (R.N.A.S.; Vloot) en die Royal Flying Corps (R.F.C.; Leër) verskyn. Op 1 April 1918 het die Royal Air Force (R.A.F.) sy gskiedenis as 'n selfstandige organisasie begin.

In Duitsland was die Feldflieger-Abteilungen oorspronklik by die weermag ingedeel, maar in 1916 is besluit of die Deutsche Luftstreitkräfte, die voorloper van die Luftwaffe, as 'n afsonderlike militêre organisasie daar te stel.

In Rusland het in 1917 die General Command of the Aerial Fleet, Aviation Supply Depots, and Inspectorate tot stand gekom, terwyl die V.S.A. se militêre vliegtuie in 1918 aan die Seinkorps onttrek is en as Air Service, U.S. Army bekend gestaan het.

In Engeland het lord Trenchard reeds geruime tyd die militêre vliegtuig veral as ' $n$ aanvalswapen gesien - ' $n$ standpunt wat na die Eerste Wêreldoorlog sterk byval gevind het en die toekomstige ontwikkeling van die militêre lugvaart sou beïnloed.

Ook die Italiner Giulo Douhet het die militêre denke op lugvaartkundige gebied beïnvloed deur vir 'n onafhanklike lugmag te pleit wat aangewend moet word om lugoorwig ten behoewe van landoperasies te verkry en om die moreel van die bevolking te beïnvloed.

In Engeland is tussen 1920 en 1930 troepe-en vliegtuigdraers aangeskaf, in Duitsland het die Luftwaffe as 'n onafhanklike deel van die Duitse Weermag te 
voorskyn getree en op 1 Februarie 1920 het die South African Air Force (S.A.A.F.) sy verskyning gemaak.

Die Tweede Wereldoorlog het onder meer enersyds bewys dat Douhet se teorieë nie in alle opsigte geldigheid kon geniet nie. Andersyds is sy voorspellings mei betrekking tot die belangrikheid van strategiese bomming en die waarde van lugaanvalle ten opsigte van gronddoele bewaarheid.

Die skrywer wys vervolgens op die uitwerking van strategiese bomming ten opsigte van Duitsland en die feit dat die Tweede Wêreldoorlog ' $n$ belangrike toetstydperk met betrekking tot die lugoorlog was.

$\mathrm{Na}$ die Tweede Wêreldoorlog het die tegniese vorderinge, veral op die gebied van kernwapens, nuwe vergesigte en voorheen onbekende vraagstukke geskep.

Die skrywer huldig die mening dat, in geval van 'n onbeperkte kernoorlog, die rol van die lugwapen allesoorheersend en beslissend sal wees.

Ten opsigte van beperkte oorlogvoering is die skrywer van mening dat dit van die geaardheid en die mate van beperking afhang. Hy wys ten slotte op 'n uitspraak van McCloskey dat dit die groot taak is om "controllable forces" te besit, "which can provide a flexible response to any level of aggression, supported by strategic superiority at the highest level of conflict, if we are to ensure a credible deterrent posture for the future."

Die Suid-Afrikaanse Lugmag het volgens hom, die groot voordeel dat dit van die begin af onder een departement geressorteer het, waardeur die vraagstuk van selfbeskikking en samewerking, wat aanvanklik in ander lande gesamentlike optrede belemmer het, nie as 'n stagnerende faktor gewerk het nie.
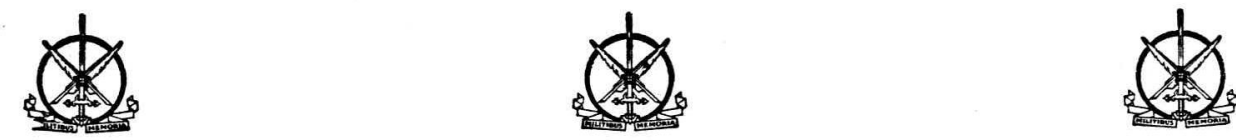